\title{
Effect of temperature and modified atmosphere packaging on globe artichoke (Cynara scolymus L.) quality during storage
}

\begin{abstract}
Two experiments were carried out on globe artichoke cultivar "French Hyrious" in the winter seasons of 2013/2014 and 2014/2015 in private farm at Behiera Governorate and in Horticulture Research Institute, Agricultural research Center postharvest laboratory to study the physical and chemical changes in the heads. To improve the storage ability of the heads, two kinds of cold storage, two types of packages were examined. Stored heads under cold storage conditions of $0^{\circ} \mathrm{C}$ and $95 \%$ R.H. were much better than those stored at $5^{\circ} \mathrm{C}$ and $95 \%$ R.H as it possessed the lower loss in weight and unmarketable percentage beside maintained the higher visual quality and colour in addition to contain more concentrations of T.S.S., total sugars, inulin, ascorbic acid and lower respiration rate. On the other hand, the heads stored in plastic boxes either lined with perforated polypropylene or unlined under $0^{\circ} \mathrm{C}$ or $5^{\circ} \mathrm{C}$ and $95 \%$ R.H exhibited that lined plastic boxes existed lower loss in weight, unmarketable percentage, higher visual quality, greater colour retention and kept more concentrations of T.S.S., total sugars, inulin, ascorbic acid beside lower respiration rate comparatively to those heads stored in the unlined ones.
\end{abstract}

Keywords: globe artichoke, polypropylene, TSS, total sugars, inulin, ascorbic acid
Volume 6 Issue 5 - 2017

\author{
Haggag IAA,' Shanan SA,' Abo El-Hamd \\ ASA,' Helaly AA,' El-Bassiouny REI' \\ 'Horticulture Department, Al-Azhar University, Egypt \\ ${ }^{2}$ Horticulture Research Institute, Agriculture Ministry -Giza, \\ Egypt
}

\begin{abstract}
Correspondence: Helaly AA, Horticulture Department, Faculty of Agriculture,Al-Azhar University, Cairo, Egypt,
\end{abstract} Email alaahelaly@hotmail.com

Received: December 27, 2016 | Published: March 14, 2017

\section{Introduction}

Globe artichoke (Cynara scolymus, L.) is a perennial plant which belong to the Asteraceae family, originating from the Mediterranean region where it is traditionally cultivated and commonly consumed as an important vegetable. ${ }^{1-3}$ Artichoke flower heads (or capitula) are immature composite inflorescences, including the edible part of the plant used worldwide as a fresh, frozen, or canned foodstuff. Moreover, artichoke industrial by-products (stems, outer bracts, leaves) represent about $80 \%$ of the biomass and may be used as raw material for the extraction of food additives and antioxidants. ${ }^{4,5}$ In addition, leaves, stems and industry residues are used for cattle feed. This vegetable crop possess an important nutrition value and medicinal uses due to its high contents of phenolic compounds, flavonoids, inulin, heparaxal, fibers and many minerals beside it contain cynarin which has effects on hepatobitary diseases, hyperlipidaemia, dropsy, rheumatism and cholesterol metabolism. ${ }^{6-8}$

Optimum temperature of storage was mainly the major factor for extending the storage ability of vegetables by minimizing both the physical, chemical and biochemical changes. Hence, it was shown from the studies done on the heads of globe artichoke during cold storage that the heads stored at $0^{\circ} \mathrm{C}$ lost $0.8 \%$ after 16 days of cold storage while those stored at 6 and $9^{\circ} \mathrm{C}$ lost 1.3 and $2.9 \%$ respectively whereas the heads stored at $17^{\circ} \mathrm{C}$ could not been prolonged for more than 10days of storage. ${ }^{9}$ The same conclusion was observed on, broccoli, as the spears stored at $20^{\circ} \mathrm{C}$ reflected rapid decrease in weight comparatively to those stored at $0^{\circ} \mathrm{C}$ which exhibited less decree. ${ }^{10}$ It was noticed cauliflower that the curds stored at $0^{\circ} \mathrm{C}$ were much better in visual quality and marketable curds than those stored at $0^{\circ} \mathrm{C}+10^{\circ} \mathrm{C}$ for 2 days. ${ }^{11}$ From the other point of view, the other experiment on broccoli revealed that the content of T.S.S in the spears stored for 3 weeks at $2 \pm 1{ }^{\circ} \mathrm{C}$ was more than those stored at $12 \pm 1{ }^{\circ} \mathrm{C} .{ }^{12} \mathrm{In}$ the same subject, it was noticed on globe artichoke that heads stored at $0,2,5,7$ and $10^{\circ} \mathrm{C}$ for 14 days showed decreases in ascorbic acid content with the progress of the storage period with the superiority of $0^{\circ} \mathrm{C}$ in keeping the highest concentrations of ascorbic acid during storage ${ }^{13}$ Extending of experiments on globe artichoke indicated that total sugars and inulin contents decreased continuously during 28 days of storage at $4^{\circ} \mathrm{C}$ and $8^{\circ} \mathrm{C}$ and those heads stored at $4^{\circ} \mathrm{C}$ kept more sugars and inulin contents than the ones stored at $8^{\circ} \mathrm{C} .{ }^{14}$

In addition, packaging is one of the important supplemental tools for cold storage to keep more good qualities for better marketing. Thus, it was found on globe artichoke that the stored heads at $4^{\circ} \mathrm{C}$ in polyethylene bags showed minimum loss in weight, unmarketable heads and maximum visual quality than the unpacked ones. ${ }^{15}$ This view was assured on cauliflower as the stored curds at $0^{\circ} \mathrm{C}$ in polypropylene or polyvinyl chloride bags Kept more T.S.S. and total sugars than those unpacked ones. ${ }^{16,17}$ Further study on another crop, globe artichoke, indicated that the heads stored at $5^{\circ} \mathrm{C}$ in perforated polypropylene bags kept comparatively the highest content of ascorbic acid than those stored in polyvinyl chloride, polyethylene or micro perforated polypropylene bags after 8 days of storage. ${ }^{18}$ Concerning the respiration rate, it was noticed on broccoli that the spears packed in polypropylene and stored at $4^{\circ} \mathrm{C}$ and $13^{\circ} \mathrm{C}$ depressed $\mathrm{O}_{2}$ and increased $\mathrm{CO}_{2}$ inside the bags which depends to great extent on respiration rate, permeability of the used films and storage temperature. ${ }^{19}$ Thus, the present work gave spot light on the extend of storage ability and improve of quality by some postharvest tools such as cold storage and packing types.

\section{Materials and methods}

Artichoke heads of the cultivar "French Hyrious" were used in this investigation where the plants grown in private farm located at Kom EL-Farag village near Abu EL-Matameer, Behiera Governorate during the two successive winter seasons of 2013-2014 and 2014-2015. This 
work was carried out to study the effect of cold storage and type of packages upon the quality of stored head. The head samples were harvested and transported within 3 hours from harvest to the laboratory of the Vegetables Department, Agriculture Research center, Ministry of Agriculture. They were cooled at $5{ }^{\circ} \mathrm{C}$ and $95 \% \mathrm{RH}$ for 24 hours after which the heads were packed in plastic boxes $(40 \times 28 \times 15 \mathrm{~cm})$ either lined with perforated polypropylene (4 holes in $\mathrm{cm}$ with $0.5 \mathrm{~mm}$ in diameter) or unlined, weighted then stored at 0 or $5^{\circ} \mathrm{C}$ and $95 \% \mathrm{RH}$ for 1,2,3 and 4weeks respectively. All artichoke samples of the two seasons were represented in three replicates comprised 4 heads each. Three randomly selected boxes of each treatment were devoted to the following characteristics before and after storage:

i. Physical changes: Loss in weight percentage, unmarketable head percentage, visual quality and colour.

ii. Chemical and biochemical changes: Total soluble solids, total sugars, inulin, ascorbic acid and the ratio between oxygen and carbon dioxide.

\section{Determination procedures}

The average changes of the heads were determined by the following procedures:

loss in weight percentage: The percentage of loss in weight was calculated by the following equation: Loss in weight $\%=$ Loss in weight at the sampling date/The initial weight of the heads*100 Unmarketable percentage: The percentage of unmarketable examined heads was determined from the following equation: Unmarketable heads $(\mathbf{\%})=$ Total number of unmarketable at the sampling date/The initial number of heads $* 100$

\section{Visual quality}

The visual quality was determined according to the scale of scoring system as explained after Able et al., [20]. They were: 9: excellent, 7: good, 5: fair, 3: poor and 1: unsuitable. This scale depends on the morphological defects such as shriveling, loss of compactness and presence of physiological and pathological defects.

\section{Colour}

The colour of the examined part was determined by Minolta (CR400, Minolta. Japan), according to the International commission of Illumination: (L*) Lightness, (a*) Red/Green, (b*) Yellow/Blue, $\left(\mathrm{C}^{*}\right)$ Chroma and $\left(\mathrm{h}^{*}\right)$ Hue angel were recorded for three pieces per sample..$^{21}$

\section{Total soluble solids (T.S.S)}

The T.S.S content were determined by abbe refractometer as a percentage as reported in A.O.A.C., (1990). ${ }^{22}$

Total sugars: The total sugars content was determined as $g / 100 \mathrm{~g}$ dry weight according to Smith et al., (1956). ${ }^{23}$

Inulin: The inulin content was determined after the method of Winton and Winton, (1958). ${ }^{24}$

Ascorbic acid: The ascorbic acid content was determined as $\mathrm{mg} \backslash 100 \mathrm{~g}$ fresh weight using 2,6 dichlorophenol indophenol method described in A.O.A.C.(1980).

\section{Results}

\section{Physicalchanges}

Loss in weight percentage: The effect of cold storage temperatures and types of packing on the artichoke head loss in weight percentage in the two seasons of 2013-2014 and 2014-2015 are presented in Table 1. It is clear that a continuous gradual loss in weight happened in heads with the extend of the storage periods in all the treatments. The resulted data of cold storage proved that the low temperature of $0^{\circ} \mathrm{C}$ was much better in lessening this percentage than the other one either in lined or unlined boxes. On the other hand, evidences show that heads stored in lined boxes loss less weight as compared with those stored in the unlined ones under both the two degrees of cold storage. In other words, the heads stored under $0 \mathrm{oC}$ in lined boxes kept the lowest loss in weight percentage and the longest storage periods.

Unmarketable percentage: The data of the effect of cold storage temperatures and types of packing on the artichoke head unmarketable percentage in the two seasons of 2013-2014 and 2014-2015 are shown in Table 2. The general view of cold storage and packing reflect an increase trend in the unmarketable percentage of the heads with the prolongation of the storage periods in all the tested experiments. The data of cold storage showed that the low temperature of $0^{\circ} \mathrm{C}$ kept more preferable values in this percentage by lowering the unmarketable heads than the other degree of temperature either in lined or unlined boxes. Dealing with packing, evidences caught from the trails showed that the heads stored in lined boxes exerted lower unmarketable percentage during storage at both $0^{\circ} \mathrm{C}$ and $5^{\circ} \mathrm{C}$ than those stored in the unlined ones. From these results, it is evident that the storage under $0^{\circ} \mathrm{C}$ in lined boxes was the best in lowering the percentage of unmarketable heads and extending the storage periods.

\section{Visual quality}

The effect of cold storage temperatures and types of packing on the artichoke head visual quality in the two seasons of 2013-2014 and 2014-2015 are clarified in Table 3. Generally speaking, the head visual quality put forth a picture of a gradual deteriorations in this characteristic with the extend of storage periods. Considerable attention to the data of cold storage presented that the temperature of $0^{\circ} \mathrm{C}$ reserved better visual qualities during storage than the other one of $5^{\circ} \mathrm{C}$ either in lined or unlined boxes. From another point of view, the results of packing reflected that the heads stored in lined boxes maintained better visual quality than those stored in the unlined ones under the two temperatures of cold storage. Noteworthy to say that the heads stored under $0^{\circ} \mathrm{C}$ in lined boxes kept better visual qualities and hold more storage periods in comparison with those stored under $5^{\circ} \mathrm{C}$ in the unlined ones.

\section{Colour}

The effect of cold storage temperatures and types of packing on the artichoke head colour in the two seasons of 2013-2014 and 2014-2015 are presented in Table 4. As a whole, in all the treatments a gradual deterioration occurred in the head colour with the extension of storage periods. It is clear that cold storage at $0^{\circ} \mathrm{C}$ was the most effective in minimizing the drop of this characteristic comparatively to cold storage at $5^{\circ} \mathrm{C}$ either in lined or unlined boxes. From another aspect, the heads stored in lined boxes reflect the least degradation of colour than those stored in the unlined ones under the two temperatures of cold storage. Thus, heads stored under $0^{\circ} \mathrm{C}$ in lined boxes showed more colour appearance and extended the storage periods than those kept under $5^{\circ} \mathrm{C}$ in unlined ones.

\section{Chemical and biochemical changes:}

Total soluble solids: The effect of cold storage temperatures and types of packing on the content of artichoke head T.S.S. during storage in the two seasons of 2013-2014 and 2014-2015 are illustrated 
in Table 5. A general gradual decline trend occurred in these contents due to the applications of both cold storage temperatures and types of packing materials with the elapse of storage periods. The results were in favor of using the low temperature of $0^{\circ} \mathrm{C}$ which hold more higher concentrations of T.S.S. in the heads than the other kind of cold storage of $5^{\circ} \mathrm{C}$ in each lined or unlined boxes. On the other hand, it is clear that the heads stored in lined boxes kept more high concentrations of T.S.S. comparatively with those stored in the unlined ones under the two temperatures of cold storage. In other words, heads stored under $0^{\circ} \mathrm{C}$ in lined boxes contained higher concentrations of T.S.S. and showed more storage periods than those stored under $5^{\circ} \mathrm{C}$ in unlined boxes.

Total sugars: The result of the effect of cold storage temperatures and types of packing on the total sugars content in the artichoke heads during storage in the two seasons of 2013-2014 and 2014-2015 are shown in Table 6 . The study of the view of the obtained data reflect general increases in these contents with the elongation of the storage periods in all the treatments till 14days which was followed by decreases till the last storage period at 28days. However, the resulted figures of cold storage exhibited more total sugars concentration in the heads stored at low temperature of $0^{\circ} \mathrm{C}$ in comparison with those stored at $5^{\circ} \mathrm{C}$ either in lined or unlined boxes. Dealing with packing, the obtained data indicate that the heads stored in lined boxes kept more total sugars than those stored in the unlined ones during cold storage under the two examined temperatures.

Inulin: The inulin content of the artichoke heads as affected by cold storage temperatures and types of packing in the two seasons of 20132014 and 2014-2015 is exhibited in Table 7. The figures indicate that there was a progressive increase in the head insulin content in all the tested treatments during the first 14days of storage after which a drop happened till the last 28days of storage. However, the results of cold storage show that storage under the temperature of $0^{\circ} \mathrm{C}$ was more pronounced in retarding the degradation of inulin content than the other one of $5^{\circ} \mathrm{C}$ in both lined or unlined boxes. Another picture caught from the obtained results cleared that the heads stored in lined boxes reserved more inulin content comparatively to those stored in the unlined ones under the two used temperatures in cold storage.

Ascorbic acid: The figures resulted from the effect of cold storage temperatures and types of packing on the ascorbic acid content of artichoke head in the two seasons of 2013-2014 and 2014-2015 are shown in Table 8. The general sight of the figures reflects a direction of decreases in this content with the elapse of storage periods. The vision of cold storages exhibit that the heads stored at $0^{\circ} \mathrm{C}$ hold higher concentrations of ascorbic acid than those stored under $5^{\circ} \mathrm{C}$ in the lined or the unlined boxes. On the other hand, the heads stored in lined boxes kept more higher ascorbic acid content in heads during the various storage periods than those stored in the unlined ones under the two kinds of cold storage.

Ratio of oxygen and carbon dioxide: The effect of cold storage temperatures and types of packing on the levels of $\mathrm{O}_{2}$ and $\mathrm{CO}_{2}$ gases around artichoke heads in the two seasons of 2013/2014 and 2014/2015 are tabulated in Table 9. As a general trend, it is obvious that the levels of oxygen around the heads decreased meanwhile those of carbon dioxide increased with the extension of storage periods. However, the figures of cold storage reflect that the heads stored at $0^{\circ} \mathrm{C}$ showed more oxygen levels and less carbon dioxide than those stored at $5^{\circ} \mathrm{C}$ during all the storage periods either in lined or unlined boxes. From another point of view, the heads stored in lined boxes kept less $\mathrm{O}_{2}$ and more $\mathrm{CO}_{2}$ in the around atmosphere than those stored in the unlined ones.

Table I The effect of cold storage temperatures and types of packing on the loss in weight percentage of globe artichoke head in the two seasons of 20I32014 and 20I4-20I5

\begin{tabular}{|c|c|c|c|c|c|c|c|c|}
\hline \multicolumn{9}{|c|}{ Storage Periods in Days } \\
\hline \multirow{2}{*}{ Treatments } & \multicolumn{4}{|c|}{$2013-2014$ season } & \multicolumn{4}{|c|}{$2014-2015$ season } \\
\hline & 7 & 14 & 21 & 28 & 7 & 14 & 21 & 28 \\
\hline \multicolumn{9}{|c|}{ Cold storage at $0^{\circ} \mathrm{C}$} \\
\hline Lined boxes & 1.2 & 3.24 & 5.01 & 7.02 & 1.7 & 3.86 & 5.42 & 7.35 \\
\hline Unlined boxes & 3.89 & 7.69 & 12.69 & 27.97 & 4.51 & 7.89 & 13.22 & 28.72 \\
\hline \multicolumn{9}{|c|}{ Cold storage at $5^{\circ} \mathrm{C}$} \\
\hline Lined boxes & 2.55 & 7.22 & 7.67 & 9.25 & 3.45 & 7.13 & 7.86 & 9.77 \\
\hline Unlined boxes & 7.3 & 13.76 & 20.61 & ----- & 8.78 & 13.87 & 20.1 & ----- \\
\hline
\end{tabular}

Table 2 The effect of cold storage temperatures and types of packing on the unmarketable percentage of globe artichoke head in the two seasons of 2013 2014 and 20I4-20I5

\begin{tabular}{|c|c|c|c|c|c|c|c|c|}
\hline \multicolumn{9}{|c|}{ Storage periods in days } \\
\hline \multirow{3}{*}{ Treatments } & \multicolumn{4}{|c|}{$2013-2014$ season } & \multicolumn{4}{|c|}{$2014-2015$ season } \\
\hline & 7 & 14 & 21 & 28 & 7 & 14 & 21 & 28 \\
\hline & \multicolumn{8}{|c|}{ Cold storage at $0^{\circ} \mathrm{C}$} \\
\hline Lined boxes & 0 & 0 & 0 & 20 & 0 & 0 & 0 & 20 \\
\hline Unlined boxes & 0 & 0 & 20 & 75 & 0 & 0 & 20 & 70 \\
\hline \multicolumn{9}{|c|}{ Cold Storage at $5^{\circ} \mathrm{C}$} \\
\hline Lined boxes & 0 & 0 & 20 & 60 & 0 & 0 & 25 & 60 \\
\hline Unlined boxes & 0 & 20 & 65 & 100 & 0 & 20 & 70 & 100 \\
\hline
\end{tabular}


Table 3 The effect of cold storage temperatures and types of packing on the*visual quality of globe artichoke head in the two seasons of 2013-2014 and 20142015

\begin{tabular}{|c|c|c|c|c|c|c|c|c|c|c|c|c|c|}
\hline \multirow{4}{*}{ Treatments } & \multicolumn{13}{|c|}{ Storage periods in days } \\
\hline & \multicolumn{5}{|c|}{$2013-2014$ season } & \multicolumn{8}{|c|}{$2014-2015$ season } \\
\hline & 0 & 7 & 14 & 21 & 28 & 0 & 7 & 14 & & 21 & & 28 & \\
\hline & \multicolumn{13}{|c|}{ Cold storage at $0^{\circ} \mathrm{C}$} \\
\hline Lined boxes & 9 & 9 & 9 & 9 & 7 & 9 & 9 & 9 & 9 & & & & 7 \\
\hline Unlined boxes & 9 & 9 & 7 & 5 & 3 & 9 & 9 & 7 & 5 & & & & 3 \\
\hline \multicolumn{14}{|c|}{ Cold storage at $5^{\circ} \mathrm{C}$} \\
\hline Lined boxes & 9 & 9 & 9 & 7 & 5 & 9 & 9 & 9 & 7 & & 5 & & \\
\hline Unlined boxes & 9 & 7 & 5 & 3 & ----- & 9 & 7 & 5 & & 3 & & & ----- \\
\hline
\end{tabular}

Visual quality was determined using the following rating score system: Excellent=9, Good=7, Fair=5, Poor=3 and Unstable $=I$ (Able et al., 2002).

Table 4 The effect of cold storage temperatures and types of packing on the colour of globe artichoke head in the two seasons of 2013-2014 and 20I4-2015

\begin{tabular}{|c|c|c|c|c|c|c|c|}
\hline \multirow{2}{*}{ Treatments } & \multirow{2}{*}{ Storage periods in days } & \multicolumn{3}{|c|}{$2013-2014$ season } & \multicolumn{3}{|c|}{$20 \mid 4-2015$ seson } \\
\hline & & $(L *)$ & $(C *)$ & $(h *)$ & $\left(L^{*}\right)$ & $\left(C^{*}\right)$ & $\left(h^{*}\right)$ \\
\hline \multicolumn{8}{|c|}{ Cold storage at $0^{\circ} \mathrm{C}$} \\
\hline & 0 & 37.22 & 18.23 & 87.28 & 37.62 & 20.99 & 85.9 \\
\hline & 7 & 37.1 & 17.83 & 86.85 & 34.2 & 19.76 & 84.33 \\
\hline \multirow[t]{5}{*}{ Lined boxes } & 14 & 36.81 & 16.68 & 86.1 & 34.12 & 18.87 & 82.55 \\
\hline & 21 & 36.76 & 16.61 & 82.03 & 33.35 & 16.56 & 79.81 \\
\hline & 28 & 33.38 & 16.54 & 80.39 & 32.85 & 16.5 & 79.58 \\
\hline & 0 & 38.57 & 19.82 & 89.04 & 40.81 & 25.3 & 91.15 \\
\hline & 7 & 34.44 & 16.07 & 75.64 & 34.21 & 20.61 & 82.85 \\
\hline \multirow[t]{3}{*}{ Unlined boxes } & 14 & 32.67 & 15.97 & 74 & 33.14 & 18.46 & 75.57 \\
\hline & 21 & 31.9 & 15.16 & 72.57 & 32.88 & 18.1 & 75.37 \\
\hline & 28 & 30.93 & 15.12 & 64.56 & 31.04 & 17.14 & 63.71 \\
\hline \multicolumn{8}{|c|}{ Cold storage at $5^{\circ} \mathrm{C}$} \\
\hline & 0 & 41.1 & 19.49 & 93.31 & 36.67 & 22.98 & 93.19 \\
\hline & 7 & 40.63 & 19.03 & 88.63 & 35.87 & 17.66 & 80 \\
\hline \multirow[t]{5}{*}{ Lined boxes } & 14 & 38.48 & 18.47 & 84.14 & 35.4 & 17.57 & 74.53 \\
\hline & 21 & 37.61 & 17.01 & 83.55 & 35.27 & 16.23 & 68.78 \\
\hline & 28 & 37.13 & 16.6 & 83.51 & 31.3 & 15.85 & 61.02 \\
\hline & 0 & 37.55 & 17.86 & 88.1 & 37.6 & 21.55 & 84.76 \\
\hline & 7 & 36.2 & 17.57 & 77.84 & 34.8 & 18.85 & 78.95 \\
\hline \multirow[t]{3}{*}{ Unlined boxes } & 14 & 36 & 15.54 & 77.59 & 33.49 & 17.57 & 74.49 \\
\hline & 21 & 33.41 & $|4.8|$ & 71.14 & 33.12 & 17.45 & 72.15 \\
\hline & 28 & ---- & ---- & ---- & ---- & ----- & ----- \\
\hline
\end{tabular}

Color was quantified using a chromameter (CR-400, Minolta, Japan). (L*) lightness, ( $\left.\mathrm{C}^{*}\right)$ Chroma, (h*) Hue angel 
Table 5 The effect of cold storage temperatures and types of packing on the total soluble solids percentage of globe artichoke head in the two seasons of 20I3-20I4 and 2014-20I5

\begin{tabular}{|c|c|c|c|c|c|c|c|c|c|c|c|}
\hline \multicolumn{12}{|c|}{ Storage periods in days } \\
\hline \multirow{3}{*}{ Treatments } & \multicolumn{6}{|c|}{$2013-2014$ season } & \multicolumn{5}{|c|}{$2014-2015$ season } \\
\hline & 0 & 7 & & 14 & 21 & 28 & 0 & 7 & 14 & 21 & 28 \\
\hline & \multicolumn{11}{|c|}{ Cold storage at $0^{\circ} \mathrm{C}$} \\
\hline Lined boxes & 13.2 & & 12.8 & 12.4 & 11.9 & II & 13.5 & I3.I & 12.6 & 12.4 & $\mathrm{II} .5$ \\
\hline Unlined boxes & 13.2 & & 12.3 & 11.8 & 10.9 & 9.8 & 13.5 & 12.7 & 12.2 & 11.3 & 10.2 \\
\hline \multicolumn{12}{|c|}{ Cold storage at $5^{\circ} \mathrm{C}$} \\
\hline Lined boxes & 13.2 & 12.7 & & 12.2 & 11.5 & 10.3 & 13.5 & 13 & 12.4 & 11.6 & 10.5 \\
\hline Unlined boxes & 13.2 & 11.7 & & II.I & 10 & ---- & 13.5 & 12 & 11.3 & 10.2 & ---- \\
\hline
\end{tabular}

Table 6 The effect of cold storage temperatures and types of packing on the total sugars (g/I00g.d.w) of globe artichoke head in the two seasons of 20I3-20I4 and 20I4-20I5

\begin{tabular}{|c|c|c|c|c|c|c|c|c|c|c|}
\hline \multicolumn{11}{|c|}{ Storage periods in days } \\
\hline \multirow{3}{*}{ Treatments } & \multicolumn{5}{|c|}{$2013-2014$ season } & \multicolumn{5}{|c|}{$2014-2015$ season } \\
\hline & 0 & 7 & 14 & 21 & 28 & 0 & 7 & 14 & 21 & 28 \\
\hline & \multicolumn{10}{|c|}{ Cold storage at $0^{\circ} \mathrm{C}$} \\
\hline Lined boxes & 27.34 & 29.94 & 30.11 & 26.29 & 22.08 & 26.15 & 28.81 & 29.77 & 25.87 & 21.37 \\
\hline Unlined boxes & 27.34 & 27.7 & 29.37 & 25.18 & 19.67 & 26.15 & 26.43 & 28.76 & 24.77 & 18.64 \\
\hline \multicolumn{11}{|c|}{ Cold storage at $5^{\circ} \mathrm{C}$} \\
\hline Lined boxes & 27.34 & 28.85 & 29.87 & 25.34 & 20.31 & 26.15 & 26.51 & 28.89 & 24.83 & 19.94 \\
\hline Unlined boxes & 27.34 & 27.42 & 28.54 & 20.21 & ----- & 26.15 & 26.31 & 26.88 & 18.89 & ----- \\
\hline
\end{tabular}

Table 7 The effect of cold storage temperatures and types of packing on the inulin(g/l00g.d.w) of globe artichoke head in the two seasons of $2013-2014$ and 20I4- 2015

\begin{tabular}{|c|c|c|c|c|c|c|c|c|c|c|}
\hline \multicolumn{11}{|c|}{ Storage periods in days } \\
\hline \multirow{3}{*}{ Treatments } & \multicolumn{5}{|c|}{$2013-2014$ season } & \multicolumn{5}{|c|}{$2014-2015$ season } \\
\hline & 0 & 7 & 14 & 21 & 28 & 0 & 7 & 14 & 21 & 28 \\
\hline & \multicolumn{10}{|c|}{ Cold storage at $0^{\circ} \mathrm{C}$} \\
\hline Lined boxes & 15.53 & 16.57 & 17.54 & 14.98 & 11.97 & 14.86 & 15.89 & 16.75 & $|3.5|$ & 11.16 \\
\hline Unlined boxes & 15.53 & 15.83 & 16.36 & 13.21 & 8.93 & 14.86 & 15.16 & 15.91 & $|2.8|$ & 8.04 \\
\hline \multicolumn{11}{|c|}{ Cold storage at $5^{\circ} \mathrm{C}$} \\
\hline Lined boxes & 15.53 & 15.95 & 16.61 & 13.89 & 9.65 & 14.86 & 15.21 & 15.98 & 12.93 & 8.87 \\
\hline Unlined boxes & 15.53 & 15.62 & 16.05 & 12.52 & ----- & 14.86 & 14.98 & 15.23 & II.78 & ----- \\
\hline
\end{tabular}

Table 8 The effect of cold storage temperatures and types of Packing on the ascorbic acid(mg//00g.f.w) of globe artichoke head in the two seasons of 20I32014 and 2014- 2015

\begin{tabular}{|c|c|c|c|c|c|c|c|c|c|c|}
\hline \multicolumn{11}{|c|}{ Storage Periods in Days } \\
\hline \multirow{3}{*}{ Treatments } & \multicolumn{5}{|c|}{$2013-2014$ season } & \multicolumn{5}{|c|}{$2014-2015$ season } \\
\hline & 0 & 7 & 14 & 21 & 28 & 0 & 7 & 14 & 21 & 28 \\
\hline & \multicolumn{10}{|c|}{ Cold storage at $0^{\circ} \mathrm{C}$} \\
\hline Lined boxes & 16.35 & 14.4 & 12.67 & II & 8.2 & 18.4 & 16 & $|4.1|$ & 12.32 & 9.17 \\
\hline Unlined boxes & 16.35 & 12.1 & 10 & 8.59 & 6 & 18.4 & 14.62 & 11.73 & 9.52 & 6.4 \\
\hline \multicolumn{11}{|c|}{ Cold storage at $5^{\circ} \mathrm{C}$} \\
\hline Lined boxes & 16.35 & 12.21 & 10.02 & 8.81 & 5.53 & 18.4 & 14 & 11.78 & 9.87 & 6.65 \\
\hline Unlined boxes & 16.35 & 10.4 & 7.83 & 5.72 & ----- & 18.4 & 12 & 9.03 & 6.83 & ---- \\
\hline
\end{tabular}


Table 9 The effect of cold storage temperatures and types of packing on the ratio of $\mathrm{O} 2$ and $\mathrm{CO} 2$ (\%) around globe artichoke head in the two seasons of $2013 / 2014$ and $2014 / 2015$

\begin{tabular}{|c|c|c|c|c|c|c|c|c|c|c|c|}
\hline \multicolumn{12}{|c|}{ Storage Periods (Days) } \\
\hline \multirow{2}{*}{ Treatments } & & \multicolumn{5}{|c|}{$2014-2015$ season } & \multicolumn{5}{|c|}{$2013-2014$ season } \\
\hline & & 0 & 7 & 14 & 21 & 28 & 0 & 7 & 14 & 21 & 28 \\
\hline \multicolumn{12}{|c|}{ Cold storage at $0^{\circ} \mathrm{C}$} \\
\hline \multirow{2}{*}{ Lined boxes } & $\mathrm{O}_{2}$ & 20.9 & 14.2 & 12.73 & 10 & 8 & 20.9 & 14.65 & 13.96 & 10.39 & 8.13 \\
\hline & $\mathrm{Co}_{2}$ & 0.03 & 3.51 & 4.25 & 5.81 & 6.68 & 0.03 & 3.36 & 4.2 & 5.7 & 6.53 \\
\hline \multirow{2}{*}{ Unlined boxes } & $\mathrm{O}_{2}$ & 20.9 & 20.9 & 20.9 & 20.9 & 20.9 & 20.9 & 20.9 & 20.9 & 20.9 & 20.9 \\
\hline & $\mathrm{Co}_{2}$ & 0.03 & 0.03 & 0.03 & 0.03 & 0.03 & 0.03 & 0.03 & 0.03 & 0.03 & 0.03 \\
\hline \multicolumn{12}{|c|}{ Cold storage at $5^{\circ} \mathrm{C}$} \\
\hline \multirow{2}{*}{ Lined boxes } & $\mathrm{O}_{2}$ & 20.9 & 13 & 11.93 & 8.78 & 5.68 & 20.9 & 13.11 & 12.17 & 8.99 & 6 \\
\hline & $\mathrm{Co}_{2}$ & 0.03 & 4.31 & 5.17 & 6.66 & 8.13 & 0.03 & 4.2 & 5.09 & 6.41 & 7.81 \\
\hline \multirow{2}{*}{ Unlined boxes } & $\mathrm{O}_{2}$ & 20.9 & 20.9 & 20.9 & 20.9 & ---- & 20.9 & 20.9 & 20.9 & ------ & 20.9 \\
\hline & $\mathrm{Co}_{2}$ & 0.03 & 0.03 & 0.03 & 0.03 & ------ & 0.03 & 0.03 & 0.03 & ------- & 0.03 \\
\hline
\end{tabular}

\section{Discussion}

The prime consideration in this part of the experiment is the use of the best storage temperature, relative humidity and atmospheric conditions for maintaining the highest quality of globe artichoke heads. However, refrigeration has long been recognized as the first factor for reserving the quality. Proper use of low temperature will retard respiration, other metabolic activities, aging, softening, colour changes, moisture loss, spoilage, undesirable growth and flavor changes. As the requirements of different vegetables vary widely, it is also vary among the various varieties which belong to one crop. So, it is necessary to establish this experiment to have knowledge about the most suitable cold storage temperature for globe artichoke variety "French Hyrious". Thus, maintaining the proper environment around the commodity during storage will prolongs their usefulness and may improve their quality.

As a general trend during cold storage either at $0^{\circ} \mathrm{C}$ or $5^{\circ} \mathrm{C}$, there was continuous increase in loss in weight, more appearance of unmarketable heads, reduction in the visual qualities and more degradation in colour with the prolongation of the storage periods. Moreover, it is well known that all the fresh vegetable crops including globe artichoke are consist of high water content which during storage are subjected to desiccation that lead to wilting and shriveling. ${ }^{25}$ The loss of the stored food reserves during respiration, hastening senescence, increase loss of visual quality, loss of soluble dry weight and reduction of food value. ${ }^{1,26,27}$ It is clear from the obtained results of cold storage that the heads stored at $0^{\circ} \mathrm{C}$ exhibited better results regarding the physical and chemical characteristics during all the storage periods than those stored at $5^{\circ} \mathrm{C}$. Thus, the view existed from using cold storage at $0^{\circ} \mathrm{C}$ was the best in minimizing head loss in weight, unmarketable percentage, changes in the visual qualities and colour deterioration at all the storage periods than storing at $5^{\circ} \mathrm{C}$. These results may be attributed to more reduction in respiration rate combined with lower ethylene production that led to better retention of the marketable and visual qualities ${ }^{28-30}$ in addition to more inhibition of a wide range of plant pathogens. ${ }^{31-33}$

However, an enlightenment on this result put forth a fact that with every $10^{\circ} \mathrm{C}$ increase in temperature during storage an acceleration of deterioration took place by two to three folds. ${ }^{24}$ From another point of view, the results obtained on the changes in the head chemical contents during cold storage under the two examined temperatures put spot light on a continuous loss of T.S.S. and ascorbic acid and at the same time reduction in the level of $\mathrm{O}_{2}$ and elevation of $\mathrm{CO}_{2}$ with the prolongation of the storage periods. On the other hand, total sugars and inulin contents showed gradual increases till 14days of cold storage that was followed by a decrease drop up to the end of storage periods. However, the decrease in TSS is mainly a resultant to conversion of insoluble compounds to simpler soluble forms on one side, moisture loss by transpiration or respiration on the other side. ${ }^{34-36}$

To have a look at the changes in total sugars and inulin contents during storage, it is clear that these contents increased during cold storage at first and decreased at the end. This result may be related to the use of these contents as respiration substrate at late storage periods. ${ }^{37-39}$ Nevertheless, the degradation in head ascorbic acid content during storage may be due to the fact that this vitamin was known as a catalyst in respiration and has an important role in the biological and biochemical oxidation-reduction reactions during the various vital processes occurring in the stored fruits which led to exhaust in this vitamin. ${ }^{18,40}$ The findings resulted for $\mathrm{O}_{2}$ and $\mathrm{CO}_{2}$ which show decreases in $\mathrm{O}_{2}$ and increases in $\mathrm{CO}_{2}$ during cold storage of the heads may be due to the continuous respiration process which use up $\mathrm{O}_{2}$ and produce $\mathrm{CO}_{2} \cdot{ }^{41-43}$

Concerning the packing treatment which held as a cold storage supplemental aid is one of the keys associated with the extension of the storage ability of the fresh product. The obtained results of packing manifested that the heads stored in lined boxes revealed preferable results of physical and chemical characteristics at all the storage periods comparatively to those stored in the unlined ones. The view of the packing data reflected that the heads stored in lined boxes transcended those stored in the unlined ones by decreasing the loss in weight, the unmarketable percentage, the changes in the visual quality and the colour degradation at all the storage periods. On the whole, the potential benefits of packing depends on the commodity, variety, physiological age, atmospheric composition around the commodity, 
temperature, duration of storage and film permeability. ${ }^{44}$ The obtained results may refer to some reasons mainly the following three ones. The first point show that the limitation of water vapor diffusion by the film increased the general water vapor pressure inside it and correlated with the decrease of the film permeability. ${ }^{45,46}$ The second point exhibit that the reduction in respiration rate combined with the lower of ethylene production by packing film during storage condition led to better in the unmarketable percentage, visual quality and green colour of vegetables. ${ }^{30}$ The third point implied that packing film inhibit a wide range of plant pathogens during storage and significantly improved the appearance of the stored commodity. ${ }^{47-50}$ The view of the data of packing types reflected that the heads stored in lined boxes surpassed those stored in the unlined ones in retention the maximum concentrations of the contents of T.S.S, total sugars, insulin, ascorbic acid and lessening of respiration rate in all the storage periods. These results may be related to the modification of atmosphere that reduced respiration rate which depends on the commodity, variety beside the type of film used such as permeability and thickness. ${ }^{43}$

\section{Conclusion}

In seeking to follow the results in this experiment, two points can be put in mind as recommendations for practical work. The first point recommend that cold storage at $0^{\circ} \mathrm{C}$ is the most suitable and effective for maintaining the quality during storage than that at $5^{\circ} \mathrm{C}$. The second point, suggest statement in favor of the perforated polypropylene lining boxes which were the most effective in extending the shelf life of globe artichoke and maintaining the highest nutritional contents. Thus, the best storability for globe artichoke is storing the heads under the conditions of cold storage at $0^{\circ} \mathrm{C}$ and $95 \%$ R.H in lined boxes with perforated polypropylene sheets.

\section{Acknowledgements}

Authors are grateful to Al-Azhar University, Faculty of Agriculture, Horticulture department, Government of Egypt for supporting this research project to carry out this work. The authors express their gratitude to Prof. Dr. Shamel Ahmed Shanan and Prof. Dr. Abd ElNaem Said Abd El-Rehim Professor of vegetable crops, Department of Horticulture, Faculty of Agriculture, Al-Azhar University. And Prof. Dr. Rawia El-Bassiouny Ibrahim Head of research, Postharvest Section, Horticulture Research Institute, Agriculture Research Center, Ministry of Agriculture for their constructive suggestions, supervision, advice, sincere help and valuable guidance throughout the course of this study.

\section{Conflict of interest}

The author declares no conflict of interest.

\section{References}

1. Forney C. Ressources genetics diversification artichoke (Cynara scolymus, L). Acta Hort. 1989;242:155-66.

2. Sonnante G, D Pignone, K Hammer. The domestication of artichoke and cardoon:from Roman times to the genomic age. Annals Bot. 2007;100(5):95-100.

3. Haggag IAA. Studies on developmental stages, handling and storage of globe artichoke (Cynara scolymus, L). MSc Thesis Faculty of Agriculture Al-Azhar University; 2016.

4. Ceccarelli N, Curadi M, Picciarelli P, et al. Globe artichoke as a functional food. Mediterranean Jour Nutr Metabol. 2010;3:197-201.
5. Haggag IAA, Shanan SA, Abo El-Hamd ASA, et al. Physical and chemical changes associated with head growth: Impact on maturity and harvesting age of globe artichoke (Cynara scolymus L). Al-Azhar J Agric Res. 2016;27:1-15.

6. Adzet T, Camarasa J, Laguna J. Hepatoprotective activity of polyphenolic compounds from (Cynara scolymus, L) against CCl4 toxicity in isolated rat hepatocystes. Jour Nat Prod. 1987;50(4):612-617.

7. Hammouda FM, Seif El-Nasr MM, Ismail SI, et al. Quantitative determination of the active constituents in Egyptian cultivated (Cynara scolymus,L). Inter Jour Pharmacology. 1993;31(4):299-304.

8. Helaly AA, Haggag IAA, Shanan SA, et al. Effect of chemical treatments on the quality of fresh-cut globe artichoke (Cynara scolymus, $\mathrm{L}$ ) during cold storage. Adv Plants Agric Res. 2016;5(2):00171.

9. Artes F, MI Gil, MA Conesa. Effect of storage temperature on quality of artichokses (Cynara scolymus L). Acta Hort. 2011;553:555-557.

10. Balouchi Z, Gholam AP, Mahmood G, et al. Changes of antioxidant compounds of broccoli (Brassica oleracea var italica) during storage at low and high temperatures. South Western J Hort Biol Environ. 2011;2:193-212.

11. Awad AH. Physiological studies on growth and storage of cauliflower (Brassica oleracea botrytis group, L). M.Sc Thesis Fac Agric AL-Azhar Univ; 2014.

12. Raja MM, Raja M, Imran AM, et al. Quality aspects of cauliflower during storage. Jour Inter Food Res. 2011;18:427-431.

13. Gil-Izquierdo A, Gill MI, Conesa MA, et al. The effect of storage temperature on vitamin $\mathrm{C}$ and phenolics content of artichoke (Cynara scolymus L) heads. Innov Food Sci and Emerging Technol. 2001;2:199-202.

14. Raccuia SA, Melilli MG. Effect of storage temperature and genotype on quality of globe artichoke (Cynara cardunculus. subsp. scolymus (L) Hegi) head. Acta Hort. 2007;630:449-454.

15. Del-Nobile MA, Conte A, Scrocco C, et al. New packaging strategies to preserve fresh-cut artichoke quality during refrigerated storage. Innovative Food Sci and Emerging Technol. 2009;10(1):128-133.

16. Schonhof I, Krumbein A, Bruckner B. Genotype effects on glycosinolates and sensory properties of broccoli and cauliflower. Nahrung Food. 2004;48(1):25-33.

17. Simon A, Gonzalez-fandos E, Dominyo R. Effect of film and temperature on the sensory, microbiological and nutritional quality of minimall processed cauliflower. Inter Jour Food Sci and Technol. 2008;43(9):1628-1636.

18. Gil-Izquierdo A, Gill MI, Conesa MA, et al. Influence of modified atmosphere packaging on quality, vitamin $\mathrm{C}$ and phenolic content of artichokes (Cynara scolymus L). Euro Food Technol. 2002;215:21-27.

19. Tano K, Mathias KO, Robert WL, et al. Comparative evaluation of the effect of storage temperature fluctuation on modified atmosphere packages of selected fruit and vegetables. Postharvest Bio Techenol. 2007;46(3):212-221

20. Able A, Wong JLS, Prasad A, et al. 1-MCP is more effective on a floral brassica (Brassica oleracea var.italica,L) than a leafy brassica (Brassica rapa var chinensis). Postharvest Biol Technol. 2002;26(2):147-155.

21. Gunes G, C Lee. Color of minimally processed potatoes as affected by modified atmosphere packaging and antibrowning agents. Jour Food Sci. 1997;62(3):572-575.

22. AOAC. Association of Official Agriculture Chemists:Official methods of analysis AOAC. 15th ed. USA: published by AOAC Washington DC; 1990. 
23. Smith FMA, Hamilton GDK, Geeds PA. Colorimetric method for determination of sugars and related substance. Anal Chem. 1956;28:550.

24. Winton AL, Winton KB. The analysis of foods. John Wiley and Sons Inc London; 1958. 857 p.

25. Kader AA. Postharvest biology and technology: An overview. In Postharvest Technology of Horticulture Crops Univ Calif Agricultural and Natural Resources publication. 2011;3311:39-47.

26. Abd El-Rahman SZ. Physiological studies on development, handling and storage of pepper. Ph. D Thesis, Fac Agric AL-Azhar Univ; 1990.

27. Sams CE. Preharvest factors affecting posthearvest texture. Postharvest Bio Technol. 1999;15(3):249-254.

28. Kader AA. Methods of gas mixing, sampling and analysis. Postharvest technology of horticultural crops Univ Calif Berkley Calif publ. 1992;331:15-19, pp.93-95.

29. Passam HC, Apostolopoulos G, Akoumianakis K. Artichoke quality during storage at 2 and $10^{\circ} \mathrm{C}$ in relation to the presence of the flower stalk and enclosure in polyethylene. Adv Hort Sci. 1999;13:165-167.

30. Alexopoulos AA, Akoumiana KA, Passam HC. The storage of globe artichokes under modified atmospheres. Food Agric and Environ. 2003;1(2):130-133.

31. Yahia EM. Modified and controlled atmospheres for tropical fruits. Hort Rev. 1998. p. 123-135.

32. Yahia EM. Effect of quarantine treatments on quality of fruits and vegetables. G Gonzalez editor. Stewart Rev. 2006. p. 1-18.

33. Yahia EM. Modified and controlled atmospheres. Recent advances in postharvest technologies to control fungal diseases in fruits and vegetables. Transworld Res Net work Kerale India; 2007. p. 103-125.

34. Abeles FB, Morgan PW, Saltveit ME. Ethylene in plant biology. CA: 2nd edition Academic Press Inc San Diego; 1992

35. Watada AE, NP Ko, Minott DA. Factors affecting quality of fresh-cut horticultural products. Postharvest Biol Technol. 1996;9(2):115-125.

36. Vallejo F, Francisco T, Cristina G. Health promoting compounds in broccoli as influenced by refrigerated transport and retail sale period. $J$ Agric Food Chem. 2003;51(10):3029-34.

37. Aly HH. Studies on keeping quality and storageability of cucumber fruits under organic farming system in green houses. M.Sc. Thesis Veg Crop Dep Cairo Univ; 2002.
38. Cabezas MJ, Rabert C, Bravo S, et al. Inulin and sugar contents in $\mathrm{He}$ lianthus tuberosus and Cichorium intybus tubers:Effect of postharvest storage temperature. Jour of Food Sci. 2002;67(8):2860-2865.

39. Pramanik BK, Matsui T, Suzuki H, et al. Changes in activities of sucrose synthesis and sucrose phosphate synthesis and sugar content during postharvest senescence in two broccoli cultivars. Asian Jour Plant Sci. 2004;3:398-402.

40. Kenny O, Beirne D. The effects of washing treatment on antioxidant retention in ready-to-use iceberg lettuce. International Jour Food Sci and Technol. 2009;44(6):1146-1156.

41. Kader AA, Zagory D, Kerbet EL. Modified atmosphere packaging of fruits and vegetables. Food Sci Nutr. 1989;28(1):1-30.

42. Villanueva MJ, Tenorio MD, Sagardoy M, et al. Physical, chemical, histological and microbiological changes in fresh green asparagus (Asparagus officinalis L) stored in modified atmosphere packaging. Food Chem. 2005;91:609-619.

43. Cefola M, Antuono ID, Pace B, et al. Biochemical relationships and browning index for assessing the storage suitability of artichoke genotypes. Food Res Inter. 2012;48(2):397-403.

44. Kader AA. Postharvest technology of horticultural crops. 3rd ed. Univ Calif ANR Publication; 2002.

45. Serrano M, Romero D, Guillen F, et al. Maintenance of broccoli quality and functional properties during cold storage as affected by modified atmosphere packaging. Postharvest Bio and Technol. 2006;39(1):61-68.

46. Danilcenko H, Jariene E, Aleknaviciene P, et al. Quality of jerusalem artichoke (Helianthus tuberosus L) tubers in relation to storage conditions. Not Bot Hort Agrobot Cluj. 2008;36(2):23-27.

47. Wang CY. Physiological and biochemical effects of controlled atmosphere on fruit and vegetables. Food preservation by modified atmosphere. CRC Press Boca Raton FL; 1999. p. 197-223.

48. Lee SK, AA Kader. Preharvest and postharvest factors influencing vitamin $\mathrm{C}$ content of horticultural crops. Postharvest. Bio-Technol. 2000;20(3):207-220

49. Ekman JH, JB Golding. Preliminary evaluation of storage technologies for broccoli, cauliflower and head lettuce. Acta Hort. 2006;712:201-208.

50. Jia C, Chao-Jiong X, Jia W, et al. Effect of modified atmosphere packaging on visual quality and glucosinolates of broccoli florets. Food Chem. 2009;114(1):28-37. 